Jurnal The Messenger, Vol. 12, No. 2, July 2020, pp. 192-207

P-ISSN: 2086-1559, E-ISSN: 2527-2810

DOI: $10.26623 /$ themessenger.v12i2.2244

\title{
(Opportunities) Death of Newspaper Industry in Digital Age and Covid-19 Pandemic
}

\author{
Supadiyanto ${ }^{1}$ \\ ${ }^{1}$ Study Program of Communication Science, Sekolah Tinggi Ilmu Komunikasi \\ (STIKOM) Yogyakarta, Jl. Laksda Adisucipto No. 279 Yogyakarta 55281, Indonesia \\ *Corresponding author, e-mail: supadiyantostikomyogyakarta@gmail.com
}

\begin{abstract}
Newspaper industry is entering a state of emergency in Indonesia. Dewan Pers demands that the government provide incentives to press companies during Covid-19. The growth in the number of internet users, the downward trend in advertising revenue, and the number of newspaper circulation are problems in the print media business. List of questions in this study: what are the trends in the use of internet technology and social media in Indonesia?; why did various newspaper companies in Indonesia collapse and die in the digital era?; how is the effort to save the newspaper business? Meanwhile, the research paradigm is qualitative. The time of the study is November 2019 to May 2020. The results of this research, the growth in the number of internet users has been extraordinary in the last 20 years. Signs of the newspaper era are over, strengthened by many newspaper companies turning to online media. The number of readers fell, the number of advertisers plummeted, number of copies narrowed, and the cost of producing newspapers became increasingly expensive to cause the closure of various newspaper companies. Rescue by attracting young readers and doing various innovations. Tragically, the print media industry will end and die on its own.
\end{abstract}

Keywords: Newspaper Industry, Opportunities, Collapse, Digital Age, Covid-19 Pandemic.

\section{Introduction}

The impact of the Covid-19 Pandemic on stock exchanges in the United States and United Kingdom was far more devastating compared to the impact of the pandemic in 1918-1919, 1957-1958 and 1968. It even makes economic uncertainty in unpredictable time periods (Altig et al., 2020; Baker et al., 2020). The fate of various print media companies in the midst of the 2019 Coronavirus Disease (Covid-19) Pandemic in Indonesia since the beginning of March 2020 is increasingly alarming together. One of the empirical evidence is Harian Umum Pikiran Rakyat (especially the Sunday edition)-which became the biggest newspaper published by Bandung, West Java, ended its Sunday edition on March 15, 2020--right in the midst of the Indonesian people and the world facing the pandemic of Coronavirus Disease 2019 (Covid-19). The loyal readers of the newspaper can still enjoy the news and information offerings from the Harian Umum Pikiran Rakyat regular edition Monday-Saturday. Harian Umum Koran Jakarta since January 2, 2020 eliminated the rubric of ideas containing opinions or discourse and book reviews in the newspaper published by the capital city of Jakarta. Previously in a row, Tabloid Cek\&Ricek ended its print edition on April 23, 2019. Harian Medan Bisnis closed the printed version on March 30, 2019. Koran Wawasan is not published since March 2019. Harian Joglosemar is not published since early January 2018 (last published December 30, 2017). Harian Pagi Bernas Jogja is not been published since March 1, 2018 (last published February 28, 2018). List of other print media that are not published anymore can be seen in Table 1 below.

Article History: Received May 06, 2020; Revised July 20, 2020; Accepted July 26, 2020; Published July 31,2020 
Table 1. Newspapers in Indonesia and other countries that are no longer published (2010-2020)

\begin{tabular}{|c|c|c|c|}
\hline No & Name of Newspapers & Circulation Area & $\begin{array}{l}\text { Started not to be } \\
\text { published again }\end{array}$ \\
\hline 1 & $\begin{array}{c}\text { Harian Umum Pikiran Rakyat } \\
\text { Sunday edition }\end{array}$ & West Java and its surroundings & March 15, 2020 \\
\hline 2 & $\begin{array}{c}\text { Aspiration/Opinion Rubric at } \\
\text { Koran Jakarta }\end{array}$ & Jakarta and surrounding areas & January 2, 2020 \\
\hline 3 & Tabloid Cek\&Ricek & Jakarta and surrounding areas & April 23, 2019 \\
\hline 4 & Harian Medan Bisnis & Medan and surrounding areas & March 30, 2019 \\
\hline 5 & Koran Wawasan & $\begin{array}{c}\text { Central Java and } \\
\text { surrounding areas }\end{array}$ & $\begin{array}{l}\text { end of March } \\
2019\end{array}$ \\
\hline 6 & Joglosemar & 'Eks Karesidenan Surakarta' & Januari 2, 2018 \\
\hline 7 & Harian Pagi Bernas Jogja & $\begin{array}{c}\text { Yogyakarta and surrounding } \\
\text { areas }\end{array}$ & March 1, 2018 \\
\hline 8 & Tabloid Bola & circulating nationally & $\begin{array}{c}\text { October } 23 \\
2018\end{array}$ \\
\hline 9 & Sinar Harapan & Jakarta and surrounding areas & January 2, 2016 \\
\hline 10 & Harian Umum Suara Karya & Jakarta and surrounding areas & $\begin{array}{c}\text { November } 1 \text {, } \\
2016\end{array}$ \\
\hline 11 & Jakarta Globe & Jakarta and surrounding areas & $\begin{array}{l}\text { end of } \\
\text { September } 2015\end{array}$ \\
\hline 12 & Tabloid Soccer & circulating nationally & 2015 \\
\hline 13 & Jurnal Nasional & Jakarta and surrounding areas & $\begin{array}{c}\text { November } 1, \\
2014\end{array}$ \\
\hline 14 & Tabloid Go & circulating nationally & 2006 \\
\hline 15 & Harian Pagi Jogja Raya & $\begin{array}{c}\text { Yogyakarta and surrounding } \\
\text { areas }\end{array}$ & 2011 \\
\hline 16 & KR Bisnis & $\begin{array}{c}\text { Yogyakarta and surrounding } \\
\text { areas }\end{array}$ & January 2, 2010 \\
\hline 17 & Malioboro Ekspress & $\begin{array}{c}\text { Yogyakarta and surrounding } \\
\text { areas }\end{array}$ & 2010 \\
\hline 18 & Koran Utusan Malaysia & Malaysia & August 22, 2019 \\
\hline 19 & The New York Times & United State of America & end of 2011 \\
\hline 20 & $\begin{array}{c}\text { Financial Times } \\
\text { Deutschland (FTD) }\end{array}$ & Germany & $\begin{array}{l}\text { November } 23 \text {, } \\
2012\end{array}$ \\
\hline
\end{tabular}

Note: processed from various references

Surprisingly, due to the impact of Covid-19, Australia's national news agency; The Australian Associated Press (AAP) has been dismiss 170 journalists on June 26, 2020, and close its editorial production services, pagemasters at the end of August 2020. AAP began publishing in 1935 by newspaper publisher Keith Murdoch, father of the founder of News Corp, Rupert Murdoch. AAP owned by Australian news organizations: Australia News Corp, Nine Entertainment Co., Seven West Media, and Australian Community Media (Subekti, 2020).

Previously, in the Southeast Asia Region, Koran Utusan Malaysia-the oldest and most well-known newspaper in Malaysia which had been established 80 years ago, no longer published its print edition since August 22, 2019. In the United States, print media circulation fell from 60 million in the year 1994 became only 35 million in 2018, and that 
added digital circulation. Indeed, the dimming of the newspaper business has been marked strongly by the case of 'down' the oldest newspaper company in the United States of the caliber of The New York Times (one of the best newspapers in the United States) at the end of 2011. In fact, The New York Times has sold 16 regional newspapers to Halifax Media Holdings for USD 143.000.000. During the first nine months of 2011, the newspaper company's revenue dropped dramatically by as much as seven percent, or only USD 190.000.000. Whereas in 2010, the annual advertising revenue of The New York Times company was USD 2.4 billion. Starting in early 2012, The New York Times chose to develop an online media business company only. Now, the print edition of The New York Times is still circulating in the community, despite having changed its name to the International New York Times. Due to a lack of income from newspapers, the company is renting out part of the space in its headquarters building in New York to help with operational costs. Faced with the economic crisis and the flow of the Internet, The New York Times chose to deliver news through online media. In addition to The New York Times which continue to fade, other print media in the United States that have ended their print editions are: Newsweek Magazine, The Rocky Mountain News, The Seattle Post Intelligencer, Lee Enterprises, Tribune Co., Reader's Digest Magazine (collapsed in midFebruary 2013), and the Washington Post on 5 August 2013 has also been negotiated (Tempo, 2013).

The declining trend in number of newspaper circulation befalls the world's highest circulation newspaper, which is still held by the Yomiuri Shimbun (in Japan) with a circulation of 10.000.000 copies per day. Subsequently followed by Asahi Newspaper with a circulation of 7.500 .000 copies per day. But in The thirty-third NSK-CAJ Fellowship Program at the Nippon Press Center (September 9, 2012), it was revealed that the Japanese press industry was also experiencing major problems. The problem is that Japanese young people (aged 20-30 years) have never read a newspaper. The biggest negative impact is the cause of the decline in the number of circulation of a number of newspaper publications by 1-2 million copies in the last few years. Base on Jyrki Jyrkiainen's research (2015) shows that the newspaper industry in Finland is experiencing a downward trend. Down from 24 publications in 2000 to 19 publications in 2010; and a decrease in the group's daily amount from 44 to 42.

That is a clear sign of the fall of print media management in the world and the country, slowly ending its business. Other obvious signs, reducing the number of normal pages from dozens to dozens of pages; eventually gradually reducing its circulation, experiencing a drastic decrease in advertising revenue, and losing loyal readers who continue to erode age and technology, and finally 'checkmate.'

Based on the search and extraction of the essence of the results of previous research related to the future of the newspaper, the following study was found. First, Philip Meyer (2009) in the book: 'The Vanishing Newspaper: Saving Journalism in the Information Age, ' predicts that daily newspaper readers will disappear for the last time in September 2043. Even in the first quarter of 2043 (April 2043), only left one person left who still reads the paper. Tragically, most other analysts dare to predict the destruction of newspapers will be faster. The art of managing a business amid the downward trend in newspaper circulation has long been a specialty of newspaper industry.

Second, Supadiyanto's thesis (Supadiyanto, 2014) entitled: 'Implementasi Teknologi Internet ke Kebijakan Editorial Harian Jogja dalam Orde Reformasi (Implementation of Internet Technology to the Harian Jogja Editorial Policy in the 
Reform Order).' Researchers revealed that the use of (technology) the Internet in the print media industry in the era of media convergence, on the one hand increased the number of readers of various news products produced by print media companies. It becomes 'counterproductive,' because it has a great chance of triggering a reduction in the number of lines in various print media. Supadiyanto (2013), emphasized that there was a real adverse effect on the implementation of paperless newspaper technology in the print media industry which had a major effect on the reduction in newspaper circulation; to cause print media companies to close or shift their business to digital channels.

Third, research conducted by Satria Kusuma (2016), concluded that the rapid development of the internet pushed people to access online media through devices. It was then that the printed media began to be threatened by its existence, and Satria Kusuma predicted that loyal readers of the newspaper would switch to online media. In addition, the research revealed that to maintain print media, they must be able to maintain credibility and trust in all information presented. However, this research does not clearly mention the problem formulation, research paradigm, data types, data collection techniques, and data analysis. Fourth, the challenges of managing a print media company in survival are very heavy. Stephen Michael Wilson (2005), citing the opinion of Vin Crosbie (2004) emphasizes that there are at least three basic tactics that the news industry must adopt to survive. First, it must use new technology to satisfy the needs of the audience. Second, the industry must understand that newspapers, the web or digital or wireless editions are not the total answer, but the convergence of the media unites all products in a single inevitable unity. The final step is to focus on the industry's ability to produce content and more on its unique services in providing a complete content package to readers regarding changes that require news rooms and companies to go beyond traditional definitions of 'news' and 'syndication' of news sources.

Fifth, recent research by Nur Hasni, Hafied Cangara, and Jeanny Maria Fatimah (2019) entitled: 'Endurance of the Print Media Business in the Midst of Online Media Usage in Makassar City (Harian Fajar and Harian Tribun Timur)' shows evidence that there is an increasing growth in the number of online media readers are accompanied by a decrease in the number of newspaper readers. Although advertising revenue from newspapers is still higher than online media, the growth of print media advertising is far less than the growth of advertising in online media.

Sixth, in the article entitled: 'End-Game Strategy for Declining Industries,' Katherine Rudie Harrigan and Michael Porter have identified four reasons for the decline: lifestyle changes, tastes or needs; technological change encourages substitute products with lower costs or higher quality; depreciation of customer groups; and the increased cost of complementary products creates an increase in package costs. Meanwhile, according to John Hill (2016), the business strategy undertaken to deal with the future of a turbulent media business is that the majority of traditional print publishers in the United Kingdom (UK) in particular have moved the path to online publishing to help maintain their readership and advertising revenue. But in reality, the most effective local newspaper company that has been launched into the digital world is having trouble getting a portion of its print advertising revenue. The statement was printed in the article titled: 'Strategies for a Turbulent Future?' written by John Hill in a book called: 'The British Newspaper Industry.' According to Shelley Thompson (2013), the trend of newspaper closure and staff redundancy in the United States in 2007-2008 due to economic recession, raises a question mark for how long the newspaper business can survive. The 
future projections of newspapers are believed not to last long in their paper and ink editions. Even according to the Digital Future Center (2012) print newspapers in the United States are only believed to last for five more years. In fact today (2020), newspapers in the United States still pretty much survive there. However, between 20122017, many news companies in the United States stopped publishing and switched to online media. In line with Miki Tanikawa (2017) revealed that over the last century, newspapers have adapted to great competition from all directions: news magazines, radio, television, and cable TV. But the threat to the print edition of the newspaper actually comes from online media. This forced the newspaper to change in an unprecedented way by differentiating their products. Its weaknesses in competing about timeliness can only be offset by presenting analysis and background information, unique coverage, rich narrative, and better visuals (Pew Research Center, 2006; Usher, 2010), all of which must appear on the front page.

Seventh, Stephen Michael Wilson's (2005) thesis entitled: 'Preserving the American Community Newspaper in the Age of New Media Convergence and Competition, ' that the future of print media in the USA is threatened by the convergence of new media and new competitions. In his research, Wilson quoted the idea of Vin Crosbie (President/Managing Partner of Digital Deliverance LLC), that now newspapers remain the most trusted and comprehensive source of news, but industry trends have knocked down its economic viability, potentially setting the stage for immediate collapse.

Eighth, research by Erwin Kartinawati (2017) is entitled: 'Jurnalisme Kloning di Kalangan Wartawan Kota Surakarya (Cloning Journalism among Surakarta City Journalists)' reveals that the practices of cloning journalism are rife. There are at least four reasons, namely: unclear media company rules, mutualism symbiosis between journalists, and economic motives (low salaries), as well as senior-junior relations and 'loyal friends.' This has caused the quality of journalism (news) products to be low. By extracting the results of previous studies, researchers can draw conclusions that from the eighth research results above, the fate of print media, especially in Indonesia, is currently experiencing a decline in terms of the number of readers, the amount of advertising revenue, the amount of circulation. Technically both graphically and in terms of presentation techniques and physical mediums are indeed far more advanced when compared to the Reform Order in early 1998, but the business prospects continue to be threatened. The research conducted this time has the advantage in terms of data exploration given the many cases of newspaper companies that have collapsed and closed, and some others have survived by switching to online media.

The problem formulations of this study are: what is the current trend in the use of internet technology and social media in Indonesia? Second, why do various newspaper companies in Indonesia begin to collapse, close, and totally die in the digital age? Third, how is the opportunity to save the newspaper media business based on academic analysis, basing the results of the study on the first and second questions above? Research on the death of the newspaper industry has not been much discussed in various studies. Many studies reveal various strategies so that newspapers can still exist in the media industry. This research aims to be descriptive in revealing uncontested facts about the signs of the death of the print media business in the digital age, amid the pandemic of the Covid-19 outbreak. This is the point of excellence of this research compared to the results of previous studies. 


\section{Methods}

The paradigm of this research is qualitative (postpositivistic). Researchers prefer the qualitative paradigm because they are able to explore the reality of print media industry trends in more depth. Data collection techniques by; literature review, observation, research experience, and limited group discussion. The time of this research is 7 months from November 2019 to May 2020. The data obtained from the field are then analyzed.

Analysis of the literature data that is relevant to the research topic, the content of a number of newspapers, opinions of a number of experts/observers as supporters then reflected to find the right answer to the problem that is the subject of the study. The conclusion is obtained from the reflection on the results and discussion.

\section{Results}

Landscape of Users of Internet Technology and Social Media in Indonesia

The first fact: when the results of this study took place, the world was facing a Covid-19 Pandemic. Since it was first discovered in mid-November 2019 in Wuhan China until now (read: May 4, 2020), Covid-19 has adversely affected 213 countries worldwide because it caused death in as many as 246.285 people; 3.521 .039 people were exposed to this virus, and only 1.136 .992 people were declared cured. The figures above will continue to grow higher, considering that currently developed countries such as: the United States, Italy, Britain, Spain, and France are the countries with the largest number of people killed worldwide due to Covid-19 (World Health Organization, 2020)

On the one hand, along with a policy of mass isolation or quarantine and strict social restrictions, the use of Internet technology and social media has experienced a tremendous surge. Because various countries in the world have adopted a similar policy: learning from home and working from home during the Covid-19 crisis. Suddenly the number of internet users jumped very significantly.

Based on the latest data (Internet Live Stats, 2020), the number of Internet users worldwide reaches: 4.549.095.958 people. Meaning: more than 63.34 percent of the world population has used Internet technology. At present the world's population reaches 7.781.988.559 people. The highest social media users achieved by Youtube: 7.218.829.181 people; Facebook as many as 2.489.373.487 people; Twitter 359.872.077 people; Skype 397.354.669 people; Pinterest 289.991.765; Tumblr 145.750.069 people. The extraordinary growth of internet and social media users, marks how internet technology has become a primary need equivalent to the needs of food, clothing, and shelter. Specifically the number of Internet users in Indonesia, at the end of January 2020 shows the number 171.260.000 users. The highest internet penetration is in Java (55.7 percent), Sumatera (21.6 percent), Sulawesi-Maluku-Papua (10.9 percent), Kalimantan (6.6 percent), and Bali-Nusa Tenggara (5.2 percent). Indonesia was ranked third in Asia, after China with 854.000.000 users, and India with 560.000.000 Internet users. While the number of Facebook users in Indonesia is $\mathbf{1 3 6 . 9 6 0 . 0 0 0 ~ u s e r s , ~ r a n k e d ~ s e c o n d ~ a f t e r ~ I n d i a ~}$ as many as 251.000.000 Facebook users.

World social media data, number of Facebook users: 2.449 billion users; Youtube: 2 billion users; WhatsApp: 1.6 billion users; Facebook Messenger: 1.3 billion users; Weixin/Wechat: 1.151 billion users; Instagram: 1 billion users; Douyin/Tiktok: 800 million users; QQ: 731 million users; Qzone: 517 million users; Sina Weibo: 497 million 
users; Reddit: 430 million users; Snapchat: 382 million users; Twitter: 340 million users; Pinterest: 322 million users; Kuaishou: 316 million users (Kemp, 2020).

While data in Indonesia, the number of internet users penetrates 175.4 million users, active social media users as many as 160 million users; there are 338.2 million cellular phones owned by Indonesian residents, with a population of 272.1 million. Using an average of time to access the Internet for 7 hours 59 minutes per day (United Nations, January 2020). Social media users in Indonesia as of January 2020: Facebook: 130 million users; Instagram: 63 million users; Snapchat: 5.4 million users; Twitter: 10.65 million users; Linkedin: 15 million users. Based on the survey of Indonesian Internet Service Providers Association on 2018, the majority of cellular telephone users use cellular operators providing internet services from Telkomsel (43 percent), Indosat Ooredoo (18.1 percent), XL (18 percent), Tri (11.6 percent), Smartfren (2.6 percent), and the rest are other brands. The cellular telephone brand used was Samsung (37.7 percent); Oppo (18 percent); Xiaomi (17.7 percent); Vivo (7.5 percent), Asus (3.2 percent), Iphone (3.1 percent); Lenovo (2.4 percent), Advan (1.5 percent), other brands (8.9 percent).

Based on statistical facts (numeric) above validly prove that the number of users of internet technology both in the world and Indonesia has increased very significantly at this time. The hypothesis that is worthy of proof then is the increasing number of internet accessers worldwide, including in Indonesia, has a strong influence on the decline in the number of newspaper readers, the decline in circulation, and the transfer of young and loyal newspaper readers to online media.

The second fact: when the results of this research took place, all newspaper companies already have an online site that becomes an aggregator for the existence of newspapers that are already owned. Although in practice later, the existence of various print media companies went bankrupt and then switched to managing an online media business that had previously been owned. The number of print media companies that divert business to online (digital) media is a trend that cannot be denied and denied anymore, considering that the print media business is experiencing a decline both in terms of advertising revenue, number of readers, and customers.

The third fact, based on data: https://www.worldometers.info/, the number of newspaper circulation in the universe on May 3, 2020 was 476,653,524 copies. That is: 6.1 percent of the world's population has the potential to buy retail and or subscribe to the newspaper in circulation. If it is assumed that one newspaper is read by 3 people ( 1 family), then the potential level of newspaper readability is 1.4 billion readers or 18 percent of the world's population. The level of readability is indeed still quite high with the assumptions above. But the fact is that many young people don't read newspapers anymore. This means that in one family, between parents and their children now have the habit of accessing different types of media. This means that the assumptions above can be even lower. Especially at this time, the availability of Internet technology has been almost evenly distributed in various countries (in developed and developing countries).

The fourth fact, various mass media companies (both print media, radio, television, and online) are currently also building channels on social media such as Facebook, YouTube, WhatsApps, and other social media. As has been done by various media companies that have channels on YouTube and have the largest number of subscribers in Indonesia, namely: Trans7 Official has a YouTube channel (successfully ranked fourth in Indonesia), Indosiar (eight), TransTV Official (fifteenth), Surya Citra Televisi/SCTV (eighteenth), RCTI-Layar Drama Indonesi (twentieth), MNCTV Official (twentyfifth), 
CNN Indonesia (fourtysixth), Kompas TV (fiftyfirst), Netmediatama (fiftysecond), tvoneNews (one hundred twenty first), Tribunnews.com (one hundred fifth), and other media companies. The success of various mainstream media companies to build channels on YouTube and get a large income from these social media channels, has become a new trend in media business governance. The success of Trans7 Official on the YouTube channel was ranked 4th nationwide because it was able to upload 49.415 copies and had 13.9 million subscribers that were watched 5.9 billion views (https://socialblade.com/youtube/top/country/id). Looking at the four facts above, it can be drawn an initial conclusion that Internet technology is very prospective in managing the mass media business in the present and future. Something similar happened in Malaysia. The growth of internet usage in Malaysia has an impact on the changing media landscape in Malaysia where citizen journalism is growing rapidly. The editorial room and journalists must change to face the challenges posed by citizen journalism (Taibi \& $\mathrm{Na}, 2020$ ). High internet technology penetration among young people at Malaysia can be used to increase their awareness in exercising their rights and obligations in the state so as to reduce the gap between ethnic groups (Rahim, 2018).

The Main Causes of Various Newspaper Industry Collapse and Close

Referring to Dewan Pers (2020), the number of journalists who passed the journalist certification is still 15.771 people. Since the journalist competency examination program was held in 2010 until now, the achievements regarding the implementation of journalist competency exams over the past 10 years have on average only produced 1.500 professional journalists per year; whereas the number of journalists in Indonesia currently can reach more than 125 thousand people. This means that only about 12.6 percent of journalists in Indonesia are certified. While the number of media companies in Indonesia is around 47,000 pieces of media consisting of: 43.300 cyber media, 2.503 print media, 674 radio media, and 523 television media. Concerned, from the number of media companies above, the number of media verified by Dewan Pers as of the beginning of May 2020 was only 1.311 units consisting of: 559 cyber media, and 352 print media, 20 radio media, and 380 television media (Dewan Pers, 2020).

The growth trend of online media advertising is believed to be increasing from year to year, inversely proportional to the declining trend in advertising in print media. This is because digital media is a future platform full of inevitability and futurism. While print media is a platform full of question marks in the present and future. If so, there is no choice for conventional media actors including print media to take the digital version more seriously (Wikan, 2017) The above argument is very reasonable. Dewan Pers report states that more than 1.300 print media have gone bankrupt in the past 15 years. The reason besides the declining economic performance of Indonesia in 2015, is also due to the rapid development of digital technology. Asmono Wikan, stated that the development of media technology is one of the factors that influence the condition of print media (Artini, 2017). The Covid-19 Pandemic which caused the global and national economy to be completely destroyed, certainly accelerated the 'death' of various print media companies, including electronic companies that could not survive.

The following six main reasons are caused that various newspaper companies have collapsed and closed: First, the presence of Internet technology is a big threat to the existence of paper-based print media. Equitable distribution of Internet infrastructure in a country, would certainly be an 'apocalypse' for the civilization of paper-based print media. Utilization of internet technology to support the presence of online and electronic 
media, directly or indirectly attracts print media readers to switch to consuming types of mass media integrated into the Internet network. As a result, the number of readers or print media customers is gradually reduced, massive, and systematic. This causes the number of print media readers to decrease, automatically decreasing the interest and enthusiasm of advertisers to advertise in print media. Suddenly, the domino effect subsequently resulted in many print media companies going out of business and choosing to shift their business lines to digital channels (online media). The facts of the print media business are already evident today, and there is no need to debate anymore.

Second, there is a change in the behavior of young people today who are more 'concerned' with internet technology than printed paper. According to Agung Adiprasetyo, in Sularto (2007), in 2006 as many as 16 percent of young people worldwide used Internet technology as a source of information, 42 percent of young people were still reading newspapers, 28 percent were watching television, and 10 percent were accessing from radio. From the figures above shows the Internet penetration among young people is very high, and paper-based newspapers, and radio are increasingly unpopular among young people. Even among students in Indonesia, there are currently very few students who want to read the newspaper.

Third, the migration of print media advertisers to other types of media, especially to online media. According to Danny Oey Wirianto (Chair of the Development of Digital Advertising at the Persatuan Perusahaan Periklanan Indonesia), since 2009-2011 digital advertising expenditure has increased 100 percent per year. Digital advertising expenditure (online media) in 2012 successfully earned a nominal of Rp 1 trillion, advertising spending on television amounting to Rp. 55.98 trillion, ad spending in newspapers Rp. 28.9 trillion, and ad spending in magazines and tabloids reached Rp. 2.6 trillion. Indonesia's total media ad spending reached Rp. 87.471 trillion in 2012. Indeed, ad spending for digital media is still small, but the pace of development shows positive trends every year (up). Based on the results of the AGB Nielsen survey on August 22, 2011, there was an interesting fact that 73 percent of consumers in Southeast Asia found their lives easier after reading or seeing advertisements on the Internet. Based on Nielsen Advertising Intelligence (Ad Intel) 2020, the total spending for advertising in 2019 on television, radio and print media reaches Rp. 181 trillion. This figure has increased when compared to the total ad spending in 2018 which only reached Rp. 168 trillion based on the gross rate card. Television still dominates 85 percent of the portion of ad spending with a figure of more than Rp. 143 trillion, growing 14 percent compared to 2018. While print media advertising expenditure reached more than Rp. 22 trillion and total radio advertising expenditure reached Rp. 1.7 trillion, while digital advertising expenditure (online) as much as Rp. 13.3 trillion.

Fourth, the growing awareness of the community to love the environment. Paper raw materials sourced from forest trees; obviously causing complex problems for the environment. Because the paper mills require a large supply of forest trees such as pine trees which have reached tens of years or even decades. This triggers illegal logging of forest trees. Awareness of the world's population to care for environmental sustainability; great opportunity to bring up the boycott movement not to use, buy, or read all products that come from paper; including print media (Supadiyanto., 2013).

Fifth, the relatively high production and distribution costs of newspapers cause a heavy burden on print media companies. The price of newsprint and ink are getting more expensive every year, as is the case today, as well as expensive distribution costs; making 
many print media companies choose to switch to online media business. Instead of surviving and continuing to increase the company's debt to survive, print media business managers chose the middle way to immediately end the print edition. So far, national newspaper needs 400.000 tons per year, while national production capacity is 770.000 tons per year. The supply of newsprint raw materials needed by hundreds of print media companies in Indonesia is dominated by PT Aspex Kumbong (formerly PT Aspex Paper). Foreign companies from South Korea that are able to produce 400.000 tons of newsprint per year. This means that more than 50 percent of newsprint is supplied by the company. According to data from Kompas (2008), there are still other companies producing newsprint besides PT Aspex Kumbong such as: Adi Prima (Jawa Pos Group) with a capacity of around 120.000 tons/year, Gede Karang (Pos Kota Group) with a capacity of 50.000 tons/year, Leces (90.000 tons/year), Suparma (36.000 tons/year), Surabaya Agung (40.000 tons/year), Tulung Agung (24.000 tons/year), and Belabak (10.000 tons/year). But it should be remembered that the average rise in the price of newsprint is USD 30-50 per year, often even increasing every three months. The need for national newsprint is around 400.000 tons per year, while the price of newsprint is now more than USD 1.000 per ton. In 2008 alone, the price of new newsprint was around USD 800 per ton. While prices in Europe are USD 850 per ton, and in Malaysia it reaches USD 810 per ton (Tempo, 2013).

Seeing this emergency condition, it is logical if the Dewan Pers demanded the government to immediately provide business breathing assistance, namely by proposing that the government provide incentives for the survival of the press company in times of crisis due to the Covid-19 Pandemic. The proposal was stated in a Dewan Pers letter Number: 334/DP-K/04/2020 on April 9, 2020 which was signed directly by the Chairman of the Dewan Pers (Mohammad Nuh) submitted to the Coordinating Minister for Economic Affairs of the Republic of Indonesia. The proposal contains 9 requests to save the print media business. Based on data from the Serikat Perusahaan Pers (2014), until December 2014; there are 471 members spread across 30 branches throughout Indonesia. There are 22.3 million newspaper newspapers circulating in Indonesia every day, of which 19 million are owned by members of the Serikat Perusahaan Pers. It is a big miracle, if within the next 5-10 years (2025-2030), the number of copies of newspapers circulating in Indonesia could reach 15 million copies.

Sixth, the low level of reading power and reading interest of the public reading print media in Indonesia. The low reading capacity of print media is a classic problem for this nation. Based on research conducted by Connecticut State University/CENTRAL (Miller \& McKenna, 2016) titled: 'World's Most Literate Nations' which conducted research on respondents in 61 countries in the world, found the fact that the Indonesian people's reading power in accessing newspapers is ranked fiftyfifth out of 61 countries surveyed. Indonesia is only above Georgia, Botswana, Costa Rica, South Africa, Morocco, Colombia; and far behind Thailand (fiftythird), Malaysia (fifth), Singapore (thirtyfourth). The world's population with the highest newspaper reading ability are Finland (first place), Norway (second place), Germany (third place), and Switzerland (fourth place). The issue of reading power and reading interest is serious problem and a serious threat to the sustainability of newspapers, of course the above conditions are very disturbing.

The facts above are also relevant to Bell and colleagues (2017), newspapers have experienced three significant disruptions related to consumption trends: the transition from print to digital, the rise of social media and the influence of mobile technology. That 
is a formidable challenge for print media managers. And base on the result of Linn-Birgit Kampen Kristensen and Mona Solvoll's research (2019), the reasons for the increased use of Facebook as a news source is the introduction of digital subscriptions by local online newspapers; and Facebook offers Generation Z good enough news for free through the easy and convenient system of sharing and recommending news stories within a network. The challenge is becoming increasingly difficult, because print media must also deal with extraordinary social media agility. Elizabeth Cosgrove and Ahmed Gomma (2014), stressed that the supply of information provided by the internet makes consumers want to be completely instant. The presence of the internet is indeed demanding that the print media industry use the internet as a new business model to deserve attention.

\section{Discussion}

Opportunities and Emergency Efforts to Save the Newspaper Industry in Indonesia

Looking at the facts and statistical data in the previous section, it clearly causes concern, fear, and anxiety of the managers of print media companies in the country. Nothing is not upset about the twilight of the print media industry in the world and in Indonesia today. Various giant companies are worried to see the development of the print media business, especially in the midst of the pandemic Covid-19, which is really destroying the number of retail newspaper buyers. If the print media company does not make various strategies and innovative (creative) changes in responding to the times, certainly the existence of a newspaper which is now more than 411 years old if counted since the first newspaper in the world called Relation which was printed using a printing press in Staarsburg and published by Johan Carolus in 1609 (Barus, 2010; Supadiyanto., 2013) will perish, or at least lose a large number of loyal readers. Print media companies are obliged to immediately make a mix between print media, electronic media, and online media, and even with social media in this era of media convergence and to elaborate between editorial and corporate policy management. The steps are as follows:

First, print media companies are required to carry out various innovations and business expansion that is able to combine (synergize) print media, online media, and electronic media. Second, print media companies must also work on the potential of young people (students and students) as partners in producing various news products by providing special rubrics. The low interest in reading young people in reading newspapers today, is clearly an apocalypse for newspaper civilization. Great strategies are needed to hook young people to have an emotional bond with the newspaper. Failing to attract the interest of young readers is destruction for the print media industry. Many newspaper managers in Indonesia, who were generally born in the $\mathrm{X}$ generation era, were afraid when the 'newspaper' era ran out, more simply because of the love of the print media managers on the medium of paper. For millennials (generation Y), the presence or absence of newspapers has become less important. Because they have more varied reference sources. Especially for generation Z, who was born in the 2000s until now, as if newspapers were no longer conceived. As has been done by Harian Umum Solopos, efforts to attract readers are made by creating specific rubrics and highlighting the uniqueness of the facts. This is in accordance with the results of Sri Wulan's research (2015), Harian Umum Solopos made two framing efforts through the rubric of education, namely by selecting facts to be highlighted so that they were worthy of Pawiyatan news and writing facts to be displayed to the public. Utilization of technology in the graphic field is very important for visualizing news. The culture of journalism must shift from 
practical journalism to graphic visualization journalism. This is one of the breakthroughs in maintaining the print media industry (Sjafiie et al., 2018)

Third, print media companies must carry out various internal and external improvements by synergizing editorial management policies and corporate management policies. This step is an increasingly open compromise, between the editorial room and the advertising room, which was once separated by a fortress called a fence of fire; has to be opened so that there is dialectic between the two. The risk is indeed an idealization that occurs in the newsroom. But it is no secret, almost no print media is still ideal in the midst of the deterioration of the print media business? Surely saving the permanence of print media publishing that needs financial support from the advertising division, becomes a necessity that cannot be denied.

Fourth, building Internet channels and reporting on various platforms, becoming a media niche, integrating real-time reports, encouraging innovation, investing in mobile devices, communicating with young readers, and building communities, and subscribing or free (Wikan, 2017). Wikan's idea became an alternative offer, but researchers' predictions, the risk of print media would still be 'turned off' slowly by online media and social media. Newspapers are like dinosaurs who cannot 'survive' because they run out of intake, and eventually by nature they die by themselves.

Fifth, newspaper companies must adapt new business models in highly fragmanted industrial situations, which are able to empower human resources and sources of funds effectively and efficiently; at the same time carrying out various innovations and creativity that are constantly related to the new rubric, how to write, how to present, how to sell, how to distribute, how to manage human resources and manage production infrastructure; ad management must follow the development of the advertising industry; and improving the quality of its human resources, that is, changing the mindset of all those who work in a newspaper company must always be inspired by the message that there is nothing eternal in the newspaper (Adiprasetyo, 2008).

Sixth, the elaboration of print and Internet media; print media are demanded to have high intelligence in giving birth to innovations in appearance and the appropriate reporting model for readers (Adv, 2013) In other words, print media must be able to synergize with the Internet world, namely publishing online media simultaneously with the print media, supporting each other. Although this step is difficult to maintain in the long run, given the existence of the newspaper is only a complement. Seventh, print media companies must improve the competence of journalists in the era of mass media convergence so that they are able to produce various high-quality journalistic products. Eighth, the print media company must strengthen the issues of locality in the presentation of the contents of print media.

Ninth, orbiting mass media owners to get involved in politics (becoming a politician). However, the great risk of this practice will drag the existence of print media and mass media networks owned by mass media entrepreneurs who are politicians as 'participant media' so that they will clash the idealistic values of a mass media that should be pro-public. In fact, this has been going on for a long time, until now. Tenth, print media must be able to meet the needs of the community with innovation and creativity in hardware and software (content). One of them is by integrating print media by using the Quick Response Code (QRC), and or Augmented Reality (AR) technology to access additional information on the Internet (Supadiyanto, 2013). 
Eleventh, the most extreme step that researchers have to save the print media business is, it will immediately end the print edition, and as soon as possible divert to the online or digital media business and social media. The facts show that the growth in the number of Internet users, cellular phone owners has surged. These various tools must be utilized by the managers of mass media to create news and advertising content that is able to combine with internet, cell phones, and social media.

Twelfth, to multiply the welfare of journalists in Indonesia, especially those who work in print media. In the view of the researcher, the responsibility of ensuring the welfare of the journalist profession is not only the responsibility of the media company that is the place to work, but also the responsibility of the state (government). The big idea is that journalists who have passed the Journalist Competency Test should also get professional allowance sourced from the State Budget ('Anggaran Pendapatan dan Belanja Negara/APBN') every month, bearing in mind that the journalist profession is upholding the four pillars of a democratic country and enlightening the public.

The failure of various print media companies in implementing the 12 steps to save the company above, undoubtedly led to the possibility of the death of the newspaper industry in the digital era and the larger Covid-19 Pandemic. Surely this is a formidable challenge for all print media industry managers. Learn from Japan, the digital transition period for newspapers in Japan is done by protecting printed paper and treating the digital platform as a complement (Villi \& Hayashi, 2017). The challenge of the newspaper industry to survive is indeed tough.

\section{Conclusion}

The positive impact of Covid-19, actually triggered a surge in the number of internet users in the world, including in Indonesia. The number of internet users in Indonesia has reached 175.4 million, currently, 160 million active social media users; there are 338.2 million cellular phones owned by Indonesian residents; with a population of 272.1 million. The main causes of various newspaper companies collapse and close, namely: the presence of internet technology poses a major threat to the existence of paper-based print media; changes in the behavior of young people today who are more 'care' for internet technology than printed paper; the migration of print media advertisers to other types of media, especially to online media; the growing awareness of the community to love the environment; relatively high production costs and costs for newspaper distribution; and the low reading capacity and reading interest of the public reading print media in Indonesia. There are 12 steps to rescue the print media industry that is in the middle of the gutter, as discussed in the discussion section. If the above steps are not able to overcome it, the last way to save that is by taking the most extreme steps to save the print media business is, it will immediately end the print edition, and immediately divert to the online media and social media businesses. Opportunities for the death of the print media industry are always open at any time if not properly anticipated from now as well. Meanwhile, the results of this study are still preliminary/basic, and quantitative paradigm research must be continued to explore and predict the future of print media more accurately in Indonesia. Urgent prospects for further research are how they relate to social media-based journalism, printed media-based journalism, and (digital) broadcast journalism; whether killing each other or actually complement each other. 


\section{Conflict of Interest}

The results of this study are the original work of researchers and there are no conflicts of interest related to the substance of the research content. Academic honesty has become a commitment of researcher in the work, including in this latest research.

\section{Acknowledgements}

Researcher would like thank to the Research and Community Service Center ('Pusat Penelitian dan Pengabdian Masyarakat' (PPPM)) at STIKOM Yogyakarta, and also thank to authors of various references that researcher quoted.

\section{References}

Adiprasetyo. (2008). Pemanfaatan Grey Literature di Perpustakaan. Jurnal Media Informasi Dan Komunikasi Kepustakawanan:, 3(2).

Adv. (2013). Ganti Wajah, Koran SINDO Ciptakan Generasi Semangat Baru. detik.com. Altig, D., Baker, S. R., Barrero, J. M., Bloom, N., Bunn, P., Chen, S., Davis, S. J., Leather, J., Meyer, B. H., Mihaylov, E., Mizen, P., Parker, N. B., Renault, T., Smietanka, P., \& Thwaites, G. (2020). Economic Uncertainty Before and During the COVID-19 Pandemic (No. 27418; Working Paper). https://doi.org/10.3386/w27418

amb. (2008). Pabrik Kertas Terpaksa Tutup. Kompas. https://nasional.kompas.com/read/2008/03/31/22222261/pabrik.kertas.terpaksa.cl osed

Artini. (2017). Media Perception of the Development of Digital Technology. Journal of the Press Council Edition, 15.

Baker, S. R., Bloom, N., Davis, S. J., Kost, K. J., Sammon, M. C., \& Viratyosin, T. (2020). The Unprecedented Stock Market Impact of COVID-19 (No. 26945; Working Paper). https://doi.org/10.3386/w26945

Barus, S. W. (2010). Journalism: Technical Guidelines for Writing News. Erlangga.

Bell, E. J., Owen, T., Brown, P. D., Hauka, C., \& Rashidian, N. (2017). The Platform Press: How Silicon Valley Reengineered Journalism. https://doi.org/10.7916/D8R216ZZ

Crosbie, V. (2004). "Representative American Speeches 2004-2005. Broadcast Education Association.

Dewan Pers. (2020a). Data Perusahaan Pers. Dewan Pers. https://dewanpers.or.id/data/perusahaanpers

Dewan Pers. (2020b). Sertifikasi Wartawan. Dewan Pers. https://dewanpers.or.id/data/sertifikasi_wartawan

Hasni, Nur, Cangara, H., \& Fatimah, J. M. (2019). Endurance of the Print Media Business in the Middle of the Rise of Online Media Use in Makassar City (Fajar Daily Newspaper and East Tribun Daily Newspaper). Journal of Communication Science Medialog, 2, 41-53.

Hill, J. (2016). Strategies for a Turbulent Future? in a book called: The British Newspaper Industry: The Future of the Regional Press. Palgrave Macmillan.

Internet Live Stats. (2020). Internet Usage \& Social Media Statistics. Internet Live Stats. https://www.internetlivestats.com/.

Jyrkiainen, J. (2015). Newspaper Chains in Finland 1993-2010. Journal of Media Business Studies, 9(2). https://doi.org/10.1080/16522354.2012.11073541.

Kartinawati, E. (2017). Cloning Journalism among Journalists in Surakarta City. The 
Messenger Journal, $9(1)$.

Kemp, S. (2020). POSTS TAGGED DIGITAL 2020. Datareportal. datareporta

Kristensen, L. B. K., \& Solvoll, M. (2019). Digital Payments for a Digital Generation: Disruptive Technology in Book and Local Newspaper Industries. Nordic Journal of Media Studies, 1(1), 125-136.

Kusuma, S. (2016). Print Media Position in the Middle of Online Media Development in Indonesia. Interact Journal, 5(1), 56-71.

Lebo, H. (2012). World Internet Project International Report. https://www.digitalcenter.org/reports/

Meyer, P. (2009). The Vanishing Newspaper: Saving Journalism in the Information Age. University of Missouri Press.

Miller, J. W., \& McKenna, M. C. (2016). World Literacy: How Countries Rank and Why It Matters (World's Mo). Routledge.

Murdoko Sudarmadji, A., \& Sularto, L. (2007). Pengaruh Ukuran Perusahaan, Profitabilitas, leverage, dan Tipe Kepemilikan Perusahaan Terhadap Luas Voluntary Disclosure Laporan Keuangan Tahunan. Seminar Ilmiah Nasional PESAT 2007.

Pew Research Center. (2006). The Future of News Magazines. Pew Research Center.

Rahim, S. A. (2018). Digital Experience and Citizen Participation in Bridging Ethnic Divide: An Analysis of Young Generation in Malaysia. Jurnal Komunikasi Malaysian Journal of Communication, 34(4), 154-167. https://doi.org/10.17576/JKMJC-2018-3404-09

Sjafiie, S. S. L., Hastjarjo, S., \& Muktiyo, W. (2018). Graphic Visualization in Printed Media: How Does the Use of Technology Influence Journalism Culture. Jurnal Komunikasi Malaysian Journal of Communication, 34(4), 373-385. https://doi.org/10/17576/JKMJC-2018-3404-22

Subekti, S. (2020). Kantor Berita Australia, AAP, Tutup Setelah 85 Tahun. Retrieved. Satuharapan. kantor-berita-australia-aap-closed-after-85-tahun

Supadiyanto. (2014). Implementasi Teknologi Internet untuk Harian Jogja tentang Kebijakan Editorial dalam Orde Reformasi [Universitas DIponegoro]. http://eprints.undip.ac.id/45564/

Supadiyanto. (2013). Implikasi Teknologi Digital dan Internet untuk (Paperless Newspaper) pada Industri Media Cetak di Indonesia. SEMINAR NASIONAL Seri 3 “Menuju Masyarakat Madani Dan Lestari” 2013, 687-696. https://dppm.uii.ac.id/index.php/2013/12/

Taibi, M., \& Na, T. Y. (2020). The Changes of Media Landscape in Malaysia: How Citizen Journalism Poses Threats to Traditional Media. Jurnal Komunikasi: Malaysian Journal of Communication, 36(1), 396-380.

Tanikawa, M. (2017). What Is News? What Is the Newspaper? The Physical, Functional, and Stylistic Transformation of Print Newspapers 1988-2013. International Journal of Communication, 11.

Tempo. (2013). Daftar Media Cetak Amerika yang Gulung Tika. Tempo.Co. http://www.tempo.co/read/news/2013/08/06/116502699/List-Media-PrintAmerika-yang-Gulung-Tikar

Thompson, S. (2013). The Future of Newspapers. In K. Fowler-Watt \& S. Allan (Eds.), Journalism: New Challenges. Centre for Journalism \& Communication Research Bournemouth University. 
Usher, N. (2010). In a Hamster-Wheel World, is There Room for Journalistic Creativity? Evidence from The New York Times. NeimanLab. http://www.niemanlab.org/2010/09/in-a-hamster-wheel-world-is-there-room-forjournalisticcreativity-evidence-from-the-new-york-times/.

Villi, M., \& Hayashi, K. (2017). "The Mission is to Keep this Industry Intact": Digital Transition in the Japanese Newspaper Industry. Journalism Studies, 18(8), 960977. https://doi.org/10.1080/1461670X.2015.1110499.

Wikan, A. (2017). Press Strategy in the Middle of Disruption. Journal of the Press Council, 15.

Wilson, S. M. (2005). Preserving the American Community Newspaper in an Age of New Media Convergence and Competition. Georgia State University.

World Health Organization. (2020). Coronavirusdisease (COVID-19) Situation Report10. World Health Organization. https://www.who.int/docs/defaultsource/coronaviruse/situation-reports/20200503-covid-19-sitrep104.pdf?sfvrsn=53328f46_2.

Wulan, S. (2015). Memahami Kebijakan Redaksional Rubrik Pendidikan di Surat Kabar Harian Solopos. Jurnal The Messenger, 7(2). 